\title{
Dinamika Kelompok Tani Hutan Agroforestry di Kabupaten Bandung
}

\section{Group Dynamics of Agroforestry Forest Farmers in Bandung Regency}

\author{
Dyah Ekaprasetya Manggala Rimbawati ${ }^{1}$, Anna Fatchiya ${ }^{2}$, Basita Ginting Sugihen ${ }^{2}$ \\ ${ }^{1}$ Pusat Penyuluhan, Kementerian Lingkungan Hidup dan Kehutanan RI, Jakarta \\ ${ }^{2}$ Departemen Sains Komunikasi dan Pengembangan Masyarakat, Fakultas Ekologi Manusia, \\ Institut Pertanian Bogor, Bogor
}

\begin{abstract}
A dynamic existence of forest farmer groups (KTH) and the level of contribution of group dynamics to the success of KTH require an inprovement in the group dynamics. The purpose of this study was to analyze the dynamics of agroforestry forest farmer groups and determine the factors that influence the dynamics of agroforestry forest farmer groups in Bandung regency. The sudy was conducted from February to April 2017. The study samples involved 78 peopel. Partial Least Square(PLS) was used to analyze the data. The study concludes that the dynamics of agroforestry forest farmer group is of a low category, that is, the group has a lack of ability in encouraging the members to reach the group goal. The low group dynamics elements were found on the purpose, structure, guidance and development, cohesiveness, atmosphere and group pressure, whereas the strong ones were on the elements of task function and group effectiveness. The factors causing the low group dynamics are the low level of extension roles, incompatibility of extension materials and lack of partnerships. It is also influenced by the high motivation and leadership of KTH chairman.
\end{abstract}

Keywords: agroforestry, dynamics, farmers, group

\begin{abstract}
Abstrak
Keberadaan kelompok tani hutan (KTH) yang tetap dinamis dan seberapa besar kontribusi kedinamisan kelompok terhadap keberhasilan KTH diperlukan adanya penguatan kelompok dalam hal ini dinamika kelompok. Tujuan penelitian yaitu untuk menganalisis dinamika kelompok tani hutan agroforestry dan menganalisis faktor-faktor yang mempengaruhi dinamika kelompok tani hutan agroforestry di Kabupaten Bandung. Penelitian dilaksanakan dari bulan Februari-April 2017. Jumlah sampel penelitian adalah 78 orang. Analisis data menggunakan Partial Least Square (PLS). Kesimpulan penelitian yaitu bahwa dinamika kelompok tani hutan agroforestry tergolong dalam kategori rendah yaitu kelompok kurang mampu dalam menggerakkan anggota untuk mencapai tujuan kelompok. Adapun unsur yang rendah pada tujuan, struktur, pembinaan dan pengembangan, kekompakan, suasana dan tekanan kelompok, sedangkan yang kuat adalah unsur fungsi tugas dan keefektifan kelompok. Faktor penyebab rendahnya dinamika kelompok tersebut dipengaruhi oleh rendahnya tingkatan peran penyuluh, ketidaksesuaian materi penyuluhan dan kurangnya kemitraan. Selain itu dipengaruhi oleh tingginya motivasi dan kekuatan kepemimpinan ketua KTH.
\end{abstract}

Kata kunci: agroforestry, dinamika, petani, kelompok

\section{Pendahuluan}

Pengelolaan hutan yang semula berorientasi pada hasil hutan kayu (timber based management) bergeser pada hasil hutan kayu, hasil hutan bukan kayu dan jasa lingkungan (forest resource based management) dengan berbasis pada pemberdayaan masyarakat (community based development). Sehubungan dengan perubahan paradigma tersebut, maka keberadaan hutan bukan hanya sebagai penghasil kayu tetapi juga dapat menghasilkan komoditas dan jasa lainnya dalam rangka meningkatkan keberdayaan masyarakat sekitar hutan. Pemberdayaan masyarakat sebagai upaya untuk meningkatkan kapasitas dan produktifitas ke arah kemandirian, maka akan tumbuh dan berkembang kelompok-kelompok di masyarakat sebagai pelaku dan pendukung pembangunan kehutanan.

Kelompok tani hutan (KTH) sebagai bagian dari masyarakat, selain sebagai sasaran utama penyuluhan kehutanan saat ini menjadi pelaku utama pembangunan kehutanan di tingkat bawah. Menurut Peraturan Menteri Kehutanan Nomor. P.57/MenhutII/2014 tentang Pedoman Pembinaan Kelompok Tani Hutan, KTH adalah kumpulan petani atau perorangan warga negara Indonesia beserta keluarga nya yang mengelola usaha di bidang kehutanan di dalam dan di luar kawasan hutan yang meliputi usaha hasil hutan kayu, hasil hutan bukan kayu dan jasa

${ }^{1}$ Korespondensi penulis 
lingkungan baik di hilir maupun di hulu (Kemenhut, 2014). Beberapa kegiatan pembangunan kehutanan, telah melibatkan kelompok tani hutan sebagai pelaku utama adalah Hutan Tanaman Rakyat, Hutan Tanaman Kemasyarakatan, Hutan Rakyat, KTH yang berusaha di bidang kehutanan seperti pembibitan, budidaya lebah madu, jamur tiram, ulat sutra, agroforestry/silvopasture/silvofishery dan pemanfaatan jasa lingkungan.

Dari berbagai kegiatan KTH, agroforestry merupakan suatu bentuk pengelolaan sumber daya yang memadukan kegiatan pengelolaan hutan atau pohon kayu-kayuan dengan penanaman komoditas atau tanaman jangka pendek, seperti tanaman pertanian. Agroforestry dapat memberikan manfaat antara lain manfaat ekonomi, ekologi dan sosial.

KTH yang dibentuk dan dibina belum semuanya aktif, bahkan tidak berhasil dan bubar. Disatu sisi KTH yang sudah mengembangkan usaha bidang kehutanan agroforestry sangat potensial untuk dikembangkan. Usaha yang dijalankan sudah berkembang baik, namun perlu terus dikelola secara berkelanjutan. Keberadaan KTH yang tetap dinamis dan seberapa besar kontribusi kedinamisan kelompok terhadap keberhasilan KTH diperlukan adanya penguatan kelompok dalam hal ini dinamika kelompok. Dinamika kelompok menguraikan kekuatan-kekuatan yang terdapat dalam kelompok yang menentukan perilaku kelompok dan perilaku anggota-anggotanya. Kelompok yang dinamis ditandai dengan adanya interaksi dan interdependensi antara anggota kelompok yang satu dengan anggota kelompok yang lain secara timbal balik dan antara anggota dengan kelompok secara keseluruhan (Santosa, 2006). Terkait dengan kondisi di atas maka tujuan penelitian adalah untuk menganalisis dinamika kelompok tani hutan agroforestry dan menganalisis faktor-faktor yang mempengaruhi dinamika kelompok tani hutan agroforestry di Kabupaten Bandung.

\section{Metode Penelitian}

Desain penelitian adalah penelitian deskriptif eksplanatory. Lokasi penelitian di Kabupaten Bandung, yaitu Kecamatan Cilengkrang dan Kecamatan Cileunyi. Penelitian dilakukan pada bulan Februari-April 2017. Populasi dalam penelitian ini adalah anggota KTH agroforestry yang aktif di Kecamatan Cilengkrang dan Kecamatan Cileunyi Kabupaten Bandung sebanyak 350 orang. Pengambilan sampel anggota dilakukan dengan menggunakan rumus Slovin (Riduwan, 2012) secara proportional simple random sampling yaitu 78 orang. Peubah yang diukur dalam penelitian ini adalah terdiri dari peubah bebas yaitu karakteristik internal anggota $\left(\mathrm{X}_{1}\right)$, dukungan penyuluhan $\left(\mathrm{X}_{2}\right)$, dukungan eksternal $\left(\mathrm{X}_{3}\right)$, kepemimpinan ketua $\mathrm{KTH}\left(\mathrm{X}_{4}\right)$ serta peubah tidak bebas yaitu dinamika kelompok tani hutan agroforestry $\left(\mathrm{Y}_{1}\right)$. Uji validitas dan reliabilitas telah dilakukan terhadap KTH non sampel. Data yang dikumpulkan dalam penelitian ini terdiri dari data primer dan data sekunder. Pengujian hipotesis adalah dengan menggunakan analisis pendekatan Partial Least Square (PLS). PLS adalah bagian dari Structural Equation Model (SEM) dengan pendekatan varians untuk tujuan memprediksi dan mengembangkan teori. PLS dikenal juga sebagai tekhnik permodelan lunak karena memiliki persyaratan yang fleksibel yaitu dalam hal skala pengukuran dapat digunakan pada data dengan skala apapun, ukuran sampel yang kecil dan data tidak harus berdistribusi normal (Sarwono dan Narimawati, 2015). Data yang dimasukkan ke program PLS akan dijalankan dan menghasilkan nilai koefisien masing-masing. Apabila nilai koefisien hasil $<0,7$ maka indikator tersebut harus dihilangkan dari model dan dilakukan satu persatu secara berulang sampai model akhir memiliki nilai koefisien $>0,7$.

\section{Hasil dan Pembahasan}

\section{Karakteristik Internal Anggota KTH}

Karakteristik internal anggota KTH meliputi umur, pendidikan formal, lamanya menjadi anggota kelompok, pelatihan yang diikuti dan motivasi anggota kelompok. Kondisi karakteristik internal anggota KTH umumnya pada tingkat yang rendah, baik dalam hal pendidikan formal, lamanya menjadi anggota kelompok, pelatihan yang diikuti maupun motivasi anggota kelompok, sedangkan untuk umur berada pada tingkat pertengahan kedewasaan (Tabel $1)$.

Menurut Havighurst (1974), kelompok periode yang didasarkan pada umur manusia dewasa, yaitu: (1) umur 18-30 tahun adalah masa 
Tabel 1 Karakteristik internal anggota KTH

\begin{tabular}{lcc}
\hline Karakteristik internal & Jumlah & Persentase \\
\hline $\begin{array}{l}\text { Umur (tahun) } \\
\text { Awal kedewasaan }\end{array}$ & 13 & 16,67 \\
$\quad(18-30)$ & & \\
$\quad$ Pertengahan & 47 & 60,26 \\
$\quad$ kedewasaan (31-60) & & 23,08 \\
$\quad$ Sangat dewasa (>60) & 18 & \\
$\quad$ Rataan = 48,75 tahun & & \\
Pendidikan formal (tahun) & & \\
$\quad$ Rendah (2-9) & 61 & 78,21 \\
$\quad$ Tinggi (10-16) & 17 & 21,79 \\
$\quad$ Rataan $=7,6$ tahun & & \\
Lamanya menjadi anggota kelompok (tahun) \\
$\quad$ Baru (1-9) & 48 & 61,54 \\
$\quad$ Lama (10-17) & 30 & 38,46 \\
$\quad$ Rataan =7,8 tahun & & \\
Pelatihan yang diikuti (kali) & & \\
$\quad$ Rendah (0-3) & 72 & 92,31 \\
$\quad$ Tinggi (4-7) & 6 & 7,69 \\
$\quad$ Rataan = 2 kali & & \\
Motivasi anggota kelompok (skor) & \\
$\quad$ Rendah (15-17,5) & 62 & 79,49 \\
$\quad$ Tinggi (17,6-20) & 16 & 20,51 \\
\hline
\end{tabular}

Keterangan: $\mathrm{n}=78$

awal kedewasaan (early adulthood), (2) umur 30-60 tahun adalah masa pertengahan kedewasaan (middle age), (3) umur lebih dari 60 tahun adalah masa kematangan akhir/sangat dewasa (later maturity). Berdasarkan data yang diperoleh, diketahui bahwa umur responden sebagian besar $(60,26 \%)$ berada pada rentang umur pertengahan kedewasaan (middle age). Sebagian besar responden sampai dengan umur 64 tahun masih berada pada rentang umur produktif yaitu menjadikan responden untuk dapat terlibat secara aktif dalam melakukan kegiatan usaha tani kehutanan seperti pemilihan jenis tanaman, penyediaan bibit, penyediaan lahan, penanaman dan pemeliharaan. Hal ini sesuai dengan penelitian Putra et al., (2006) bahwa responden tergolong usia produktif berarti petani memiliki kemampuan fisik yang baik. Dengan kondisi fisik yang baik, mereka dapat melakukan kegiatan secara optimal dan masih dapat mengembangkan kemampuan diri dalam hal berusahatani salak.
Pendidikan formal adalah lamanya tahun pendidikan formal yang pernah diikuti responden. Rataan pendidikan formal responden rendah 7,6 tahun yaitu hanya lulusan Sekolah Dasar. Pendidikan sebagian besar responden 78,21\% dapat dikatakan dalam kategori rendah karena mengenyam pendidikan selama dua sampai dengan sembilan tahun dalam arti responden tidak lulus pendidikan dasar dan atau lulus pendidikan pada Sekolah Dasar (SD) dan Sekolah Menengah Pertama (SMP). Hal ini menunjukkan bahwa rendahnya tingkat pendidikan dikarenakan oleh tidak adanya biaya untuk melanjutkan sekolah dan sarana prasarana yang kurang memadai serta sekolah hanya tersedia di kota yang jaraknya jauh, sehingga pendidikan hanya sebatas SD saja. Seperti hasil penelitian Riana et al., (2015) bahwa jarak tempuh yang cukup jauh dan infrastruktur yang kurang memadai di desa tempat petani tinggal dengan fasilitas pendidikan tidak mendukung untuk mereka menempuh pendidikan yang lebih tinggi serta keinginan yang lemah dan biaya pendidikan juga menjadi faktor lain sehingga mereka tidak mengencam pendidikan hingga perguruan tinggi.

Lamanya responden bergabung dengan kelompok yang terbaru adalah satu tahun dan terlama 17 tahun. Rata-rata anggota bergabung dengan kelompok yaitu 7,8 tahun. Lamanya menjadi anggota kelompok akan berdampak pada pengalaman yang dimiliki sebagai anggota kelompok. Semakin lama menjadi anggota kelompok maka pengalaman yang dimiliki lebih banyak dan juga manfaat yang diperoleh. Hal ini sejalan dengan penelitian Sudarko (2010) yang mengemukakan bahwa semakin lama bergabung dalam suatu kelompok maka semakin akan mengerti nilai-nilai kelompok dan semakin banyak partisipasi dalam kegiatan kelompok.

Keikutsertaan anggota kelompok dalam pelatihan agroforestry dalam kategori rendah yaitu sebesar 92,31\%. Responden mengikuti pelatihan hanya 1 sampai 3 kali pelatihan bahkan ada yang tidak pernah mengikuti pelatihan. Rendahnya pelatihan yang diikuti ini disebabkan karena kurangnya informasi mengenai adanya kegiatan pelatihan dan adanya kecenderungan penunjukan peserta pelatihan pada orang yang sama, seperti ketua kelompok atau pengurus kelompok saja. Hal ini sejalan dengan penelitian Ruhimat (2015) bahwa menurut petani, pendidikan dan pelatihan tentang 
penerapan sistem agroforestry jarang dilakukan dan kalau ada hanya untuk para pengurus kelompok tani.

Untuk bergabung dalam kelompok, anggota kelompok mempunyai alasan ataupun dorongan untuk melaksanakan tugas dan tanggungjawab dalam kelompok. Berdasarkan hasil penelitian menunjukkan bahwa motivasi anggota kelompok rendah yakni sebesar 79,49\%. Dalam beberapa terminilogi, motivasi dinyatakan sebagai suatu kebutuhan (needs), keinginan (wants), gerak hati (impulse), naluri (instincts) dan dorongan (drive), yaitu sesuatu yang memaksa organisme manusia untuk berbuat atau bertindak. Motivasi ada dua jenis yaitu motivasi intrinsik adalah motivasi yang timbul dari dalam diri orang yang bersangkutan tanpa rangsangan atau bantuan orang lain dan motivasi ekstrinsik adalah motivasi yang timbul karena rangsangan atau bantuan dari orang lain (Khodijah, 2014). Hasil wawancara terhadap responden mengenai motivasi diketahui bahwa ada beberapa alasan untuk bergabung dalam kelompok yaitu untuk mendapatkan ilmu pengetahuan, informasi dan meningkatkan keterampilan tentang kegiatan kehutanan. Selain itu dengan menjadi anggota kelompok akan menambah teman baru dan dapat membangun kerjasama kelompok. Apapun motivasi yang mendorong petani untuk masuk menjadi anggota kelompok, apakah itu termotivasi karena kesadaran sendiri, terpaksa/desakan dari orang lain atau hanya untuk mendapatkan keuntungan saja, tidak berpengaruh pada fungsi kelompok tani. Pada kenyataannya kelompok tetap ada dan terus berlanjut (Ramadoan et al., 2013).

\section{Dukungan Penyuluhan}

Seperti halnya pada karakteristik internal anggota KTH, dukungan penyuluhan juga berada pada tingkat yang rendah, baik dalam hal intensitas penyuluhan, tingkat peran penyuluh dan kesesuaian materi penyuluhan, sedangkan menurut responden ketepatan metode penyuluhan sudah tepat (Tabel 2). Secara lebih terinci penjelasan masing-masing dukungan penyuluhan tersebut diuraikan lebih lanjut.

Intensitas penyuluhan yang dilakukan oleh penyuluh sebagai upaya untuk mengubah perilaku anggota kelompok ke arah lebih baik dari hasil penelitian tergolong rendah 79,49\%. Intensitas penyuluhan yang terjadi diketahui bahwa penyuluh kehutanan teratur mendatangi kelompok.
Jadwalnya pun telah dijadwalkan atau direncanakan sebelumnya, bisa satu kali dalam sebulan ataupun tergantung kebutuhan. Tetapi terkadang jika melihat kelompok tanibinaannya sudah maju, maka penyuluh tidak teratur mendatanginya dan diprioritaskan pada kelompok tani yang belum maju, sehingga tidak setiap bulan penyuluh mengunjungi kelompok. Faktor utama rendahnya kunjungan penyuluh ini adalah terbatasnya jumlah penyuluh, sedangkan luas wilayah kerjanya sangat luas. Sebagai gambaran, di Kabupaten Bandung yang terdiri dari 31 kecamatan hanya terdapat dua belas orang penyuluh kehutanan di lapang, sehingga rata-rata seorang penyuluh kehutanan lapang membawahi dua sampai tiga wilayah kecamatan dengan jumlah kelompok binaan yang banyak. Terkait dengan hal ini, perlu upaya untuk meningkatkan jumlah penyuluh lapang di bidang kehutanan baik dari Pegawai Negeri Sipil (PNS), Penyuluh Kehutanan Swadaya Masyarakat (PKSM) dan Penyuluh Kehutanan Swasta.

Tabel 2. Dukungan Penyuluhan

\begin{tabular}{lcc}
\hline Dukungan penyuluhan & Jumlah & Persentase \\
\hline Intensitas penyuluhan & & \\
$\quad$ Rendah (8-10) & 62 & 79,49 \\
$\quad$ Tinggi (11-12) & 16 & 20,51 \\
Tingkatan peran penyuluh & & \\
$\quad$ Rendah (19-22.5) & 61 & 78,21 \\
$\quad$ Tinggi (22.6-26) & 17 & 21,79 \\
Ketepatan metode penyuluhan & \\
$\quad$ Kurang tepat (10-14) & 17 & 21,79 \\
$\quad$ Tepat (15-18) & 61 & 78,21 \\
Kesesuaian materi penyuluhan & \\
$\quad$ Kurang sesuai & 65 & 83,33 \\
$\quad$ (15-19,5) & 13 & 16,67 \\
$\quad$ Sesuai (19,6-24) & 13
\end{tabular}

Keterangan: $\mathrm{n}=78$

Penyuluh kehutanan dalam melakukan kegiatan penyuluhan untuk mendukung keberhasilan dan keberlanjutan kelompok memiliki tingkatan peran penyuluh sebagai edukator, motivator, fasilitator, dinamisator, konselor, mediator dan advokator. Dari hasil penelitian, bahwa tingkatan peran penyuluh tergolong kategori rendah 78,21\%. Peran penyuluh sebagai advokator yaitu penyuluh aktif membantu menyelesaikan masalah sengketa atau konflik kawasan sangat jarang terjadi sehingga penyuluh tidak terlibat didalamnya, biasanya bisa 
diselesaikan secara kekeluargaan tanpa melibatkan penyuluh. Juga peran penyuluh sebagai mediator yaitu dalam membantu kelompok bermitra dengan pihak lain dirasakan kurang, penyuluh aktif dalam membantu kelompok tentang cara-cara bermitra, tetapi anggota kadang sibuk dengan urusan masingmasing sehingga belum terlaksana.

Dukungan penyuluhan pada aspek ketepatan metode penyuluhan termasuk dalam kategori tepat $78,21 \%$. Ini mengindikasikan bahwa penyuluh kehutanan telah menggunakan metode penyuluhan kehutanan yang tepat sehingga dapat membantu menyelesaikan masalah petani hutan agroforestry. Hal ini sejalan dengan penelitian Sari et al., (2016) bahwa sebagian besar responden menunjukkan bahwa metode penyuluhan dalam kategori sangat sesuai dalam menunjang materi yang disampaikan. Ketepatan dan kesesuaian metode yang dipilih menunjang keberhasilan materi yang diberikan. Metode penyuluhan yang digunakan oleh penyuluh kehutanan bervariasi seperti menggunakan selebaran (leaflet, poster, brosur), ceramah, demonstrasi (peragaan/praktek), diskusi dan kunjungan lapang. Metode penyuluhan yang banyak digunakan adalah ceramah dan paling sedikit adalah menggunakan selebaran (leaflet, poster, brosur). Selebaran (leaflet, poster, brosur) sangat sedikit digunakan karena hanya dengan gambar maupun tulisan sulit dimengerti dan dipahami oleh responden.

Kesesuaian materi penyuluhan termasuk dalam kategori kurang sesuai 83,33\%. Materi yang diberikan oleh penyuluh kurang sesuai dengan diri responden dan kebiasaan masyarakat, juga dari bahasa (istilah) yang digunakan penyuluh sulit dimengerti oleh anggota kelompok. Sehingga sebaiknya materi yang diberikan sesuai dengan kearifan lokal masyarakat.

\section{Dukungan Eksternal}

Dukungan eksternal meliputi interaksi sosial kelompok dan tingkat kemitraan anggota KTH. Kondisi eksternal yang mendukung usaha petani hutan agroforestry berada pada tingkat yang rendah, baik dari interaksi sosial kelompok maupun tingkat kemitraan anggota KTH yang rendah (Tabel 3). Secara lebih terinci penjelasan masing-masing dukungan eksternal tersebut diuraikan lebih lanjut. Interaksi sosial kelompok berada pada kategori rendah sebesar $82,05 \%$. Interaksi sosial kelompok terkait dengan hubungannya kelompok dengan kelompok lain, dengan tokoh masyarakat, dengan penyuluh, dengan instansi kehutanan setempat dan dengan perusahaan swasta. Interaksi sosial yang tinggi ditunjukkan oleh hubungan anggota kelompok dengan penyuluh kehutanan. Hubungan dengan penyuluh kehutanan selain berlangsung pada saat kegiatan penyuluhan dan pelatihan, juga terjadi interaksi di luar kegiatan tersebut.

Tabel 3. Dukungan Eksternal

\begin{tabular}{ccc}
\hline Dukungan eksternal & Jumlah & Persentase \\
\hline Interaksi sosial kelompok & & \\
Rendah $(14-16,5)$ & 64 & 82,05 \\
Tinggi $(16,6-19)$ & 14 & 17.95 \\
Mitra kerja (kemitraan) & & \\
Rendah $(11-13,5)$ & 69 & 88,46 \\
Tinggi $(13,6-16)$ & 9 & 11,54 \\
\hline
\end{tabular}

Keterangan: $\mathrm{n}=78$

Dari hasil penelitian, bahwa kemitraan berada pada kategori rendah sebesar $88,46 \%$. Dari 78 responden, hanya 24 responden yang sudah menjalin kemitraan. Kelompok belum menjalin kemitraan dengan pihak manapun karena tidak ada yang memfasilitasi dan juga terkendala kelengkapan administrasi yang harus disiapkan kelompok. Kelompok lebih mudah bekerjasama dalam pemasaran hasil secara lisan tetapi menguntungkan biasanya dengan perorangan. Hal ini sejalan dengan penelitian Suryani et al., (2017) bahwa bentuk kemitraan tidak tertuang dalam satu bentuk perjanjian tertulis, namun berdasarkan ikatan kepercayaan antara kedua belah pihak. Meskipun demikian dengan menjalin kemitraan mengenai agroforestry dirasakan cukup bermanfaat bagi responden. Manfaat kemitraan antara lain memberikan kemudahan untuk pemasaran, membantu permodalan, menambah penghasilan dan pengetahuan serta menumbuhkan silaturahmi.

\section{Kepemimpinan Ketua KTH}

\section{Kepemimpinan ketua KTH meliputi}

peran ketua KTH dan sifat personal ketua KTH. Kepemimpinan ketua KTH berada pada tingkat yang rendah, baik peran ketua KTH maupun sifat 
personal ketua KTH (Tabel 4). Secara lebih rinci penjelasan masing-masing kepemimpinan ketua KTH tersebut diuraikan lebih lanjut.

Tabel 4. Kepemimpinan Ketua KTH

\begin{tabular}{ccc}
\hline $\begin{array}{c}\text { Kepemimpinan ketua } \\
\text { KTH }\end{array}$ & Jumlah & Persentase \\
\hline $\begin{array}{c}\text { Peran ketua KTH } \\
\text { Rendah (14-17) }\end{array}$ & 67 & 85,90 \\
Tinggi (18-20) & 11 & 14,10 \\
Sifat personal ketua KTH & & \\
$\quad$ Rendah (15-19,5) & 61 & 78,21 \\
Tinggi (19,6-24) & 17 & 21,79 \\
\hline
\end{tabular}

Keterangan: $\mathrm{n}=78$

Peran ketua KTH adalah sejauhmana ketua KTH berperan sebagai orang yang dapat mempengaruhi, mengarahkan, menggerakkan dan mengelola kelompok guna mencapai tujuan yang telah disepakati bersama. Hal ini sejalan dengan penelitian Mutmainah dan Sumardjo (2014) bahwa pemimpin kelompok tani memiliki peranan penting

dalam mengelola kelompok taninya. Dari hasil penelitian, peran ketua KTH tergolong rendah $85,90 \%$. Pengukuran dilakukan dengan melihat tingkat peran ketua KTH dalam menjelaskan tujuan kelompok kepada para anggota, memberikan sarana dan prasarana kepada para anggota, memberikan semangat dalam bekerja kepada para anggota, mendengarkan aspirasi anggota dan memberikan saran pemecahannya. Ketua KTH telah menjelaskan tujuan kelompok tani kepada para anggotanya sehingga anggota akan menjadi tahu apa tujuan yang telah disepakati bersama. Tetapi ada juga anggota yang tahu tujuan kelompok tetapi tidak memahaminya dan tidak semua anggota mempunyai keinginan dan tujuan yang sama dengan ketua KTH. Sifat personal ketua KTH harus dimiliki oleh ketua KTH untuk mencapai tujuan kelompok yang telah disepakati bersama. Pengukuran dilakukan dengan penilaian responden terhadap tingkatan sifat personal ketua KTH: cerdas, kreatif, jujur, bersahabat, percaya diri, gigih, sabar dan kuat. Dari hasil penelitian, sifat personal KTH berada pada kategori rendah 78,21\%. Ketua KTH seyogyanya harus mempunyai kemampuan dan pengetahuan tentang sesuatu hal, tetapi terkadang ketua KTH kurang mempunyai kepercayaan diri yang tinggi, sehingga sifat personal ini dirasakan masih kurang dimiliki oleh ketua KTH. Seorang pemimpin harus menaruh kepercayaan penuh kepada yang dipimpin, percaya bahwa mereka akan mampu menyelesaikan tugasnya masing-masing dengan baik. Sebaliknya kepercayaan itu harus dapat dirasakan oleh mereka yang dipimpin, sehingga semangat dan daya kerja mereka menjadi berkembang. Kepercayaan pemimpin terhadap anak buahnya hanya bisa terjadi apabila pemimpin sendiri mempunyai kepercayaan sepenuhnya pada diri sendiri yaitu percaya kepada kesanggupan dan kemampuan diri sendiri (Karjadi, 1983).

\section{Dinamika Kelompok Tani Hutan Agroforestry}

Dinamika kelompok merupakan hal penting yang perlu diperhatikan dalam penguatan dan pengembangan sebuah kelompok. Dinamika kelompok berarti adanya interaksi dan interdependensi antara anggota kelompok yang satu dengan anggota kelompok yang lain secara timbal balik dan antara anggota dengan kelompok secara keseluruhan yang akan menentukan perilaku anggota kelompok dan perilaku kelompok yang bersangkutan dalam bertindak melaksanakan kegiatan demi tercapainya tujuan bersama yang merupakan tujuan kelompok.

Dinamika kelompok dalam penelitian ini diukur berdasarkan delapan unsur sebagai berikut: tujuan kelompok, struktur kelompok, fungsi tugas kelompok, pembinaan dan pengembangan kelompok, kekompakan kelompok, suasana kelompok, tekanan kelompok dan keefektifan kelompok. Tingkat dinamika kelompok rendah 73,08\% (Tabel 5), yaitu kelompok kurang mampu dalam menggerakkan anggota untuk mencapai tujuan kelompok. Adapun unsur yang rendah pada tujuan, struktur, pembinaan dan pengembangan, kekompakan, suasana dan tekanan kelompok, sedangkan yang kuat adalah unsur fungsi tugas dan keefektifan kelompok. Secara lebih terinci penjelasan masing-masing unsur dinamika kelompok tani hutan agroforestry tersebut diuraikan lebih lanjut.

Tujuan kelompok adalah sesuatu yang ingin dicapai oleh kelompok. Tujuan kelompok tani hutan agroforestry berada pada kategori rendah yaitu sebesar 93,59\%. Persetujuan anggota dengan 
Tabel 5. Dinamika Kelompok Tani Hutan Agroforestry

\begin{tabular}{lcc}
\hline Dinamika kelompok & Jumlah & Persentase \\
\hline Tujuan kelompok & & \\
Rendah (6-7) & 73 & 93,59 \\
Tinggi (7,1-8) & 5 & 6,41 \\
Struktur kelompok & & \\
Rendah (13-15,5) & 46 & 58,97 \\
Tinggi (15,6-18) & 32 & 41,03 \\
Fungsi tugas kelompok & & \\
Rendah (13-17,5) & 13 & 16,67 \\
Tinggi (17,6-22) & 65 & 83,33 \\
Pembinaan dan pengembangan kelompok \\
Rendah (7-9,5) & 67 & 85,90 \\
Tinggi (9,6-12) & 11 & 14,10 \\
Kekompakan kelompok & & \\
Rendah (9-10,5) & 75 & 93,59 \\
Tinggi (10,6-12) & 5 & 6,41 \\
Suasana kelompok & & \\
Rendah (11-12,5) & 65 & 83,33 \\
Tinggi (12,6-14) & 13 & 16,67 \\
Tekanan kelompok & & 60,26 \\
Rendah (6-7,5) & 47 & 39,74 \\
Tinggi (7,6-9) & 31 & \\
Keefektifan kelompok & & \\
Rendah (6-8,5) & 31 & 39,74 \\
Tinggi (8,6-11) & 47 & 60,26 \\
Total dinamika kelompok & & \\
Rendah (76-87) & 57 & \\
Tinggi (88-98) & 21 & \\
\hline & & \\
\hline
\end{tabular}

Keterangan: $\mathrm{n}=78$

tujuan kelompok yang ditetapkan merupakan hal yang utama dalam unsur tujuan kelompok. Tujuan kelompok disampaikan oleh ketua kelompok tani kepada anggota kelompok agar anggota kelompok mengetahui dan menyetujui tujuan kelompok yang ditetapkan, tetapi ada juga anggota yang tidak paham dengan tujuan kelompok, sehingga tujuan kelompok belum bisa memenuhi harapan anggota. Hal ini sesuai dengan penelitian Ruhimat (2017) di Kabupaten Tasikmalaya bahwa kelompok tani telah memiliki tujuan kelompok, tetapi masih belum sesuai dengan harapan. Menurut responden penelitian tujuan KTH agroforestry antara lain meningkatkan kesejahteraan anggota kelompok tani, meningkatkan pengetahuan dan keterampilan anggota (sebagai wadah belajar bersama), sebagai tempat bermusyawarah dan memudahkan memasarkan hasil usaha tani.

Struktur kelompok tani hutan agroforestry sebagian besar berada pada kategori rendah sebesar $58,97 \%$. Struktur kelompok merupakan bentuk hubungan antara individu-individu dalam kelompok dan pengaturan peranan yang ditentukan oleh tujuan kelompok yang ingin dicapai. Struktur kelompok dalam hal ukuran dan aturan yang dipakai dalam kelompok yaitu bahwa aturan yang ada didalam kelompok biasanya tidak tertulis atau hanya secara lisan tetapi disepakati dan dilakukan bersama kelompok. Seperti larangan menebang pohon, larangan menanam sayuran di kawasan hutan lindung, petani boleh bertani di kawasan hutan dengan catatan tidak boleh membuka lahan dengan cara dibakar, dsb. Hal ini sesuai dengan penelitian Bangsawan et al., (2016) bahwa aturan ini tidak dituangkan secara tertulis tetapi semua anggota memahami dan mematuhinya.

Fungsi tugas kelompok adalah hal-hal yang harus dilakukan didalam kelompok agar kelompok dapat mencapai tujuannya yaitu memfasilitasi dan mengkoordinir usaha-usaha kelompok yang menyangkut masalah-masalah bersama dan dalam rangka memecahkan masalah tersebut. Pengukuran dilakukan berdasarkan penilaian responden terhadap tingkatan pembagian tugas, mencari informasi dan mendapatkan gagasan-gagasan yang diperlukan kelompok, adanya koordinasi, adanya inisiasi dan adanya pemecahan masalah anggota. Fungsi tugas kelompok berada pada kategori tinggi sebesar 83,33\%. Seperti halnya penelitian Damanik (2013) bahwa unsur yang paling kuat mempengaruhi dinamika kelompok adalah fungsi tugas kelompok.

Pembinaan dan pengembangan kelompok sebagian besar tergolong pada kategori rendah $85,90 \%$. Pembinaan dan pengembangan kelompok merupakan usaha untuk menjaga kelompok tetap hidup. Penyediaan fasilitas belum sepenuhnya terpenuhi (belum cukup memadai) seperti ruang pertemuan yang sempit dan peralatan yang belum lengkap. Fasilitas yang telah ada selain dari hasil swadaya kelompok juga mendapat bantuan dari pihak lain. Keterbatasan dana yang ada merupakan 
hambatan dalam penyediaan sarana prasarana. Namun demikian secara bertahap hal ini terus diupayakan untuk kelancaran kegiatan kelompok. Hal ini sejalan dengan penelitian Kusnani (2015) bahwa penyebab dari rendahnya pembinaan dan pengembangan kelompok adalah sarana dan prasarana yang belum cukup tersedia, sebagai contoh tempat dilaksanakan kegiatan pelatihan belum tersedia secara optimal.

Kekompakan kelompok merupakan kesatuan dan persatuan kelompok yang merupakan komitmen yang kuat dari seluruh anggota. Dari hasil penelitian diperoleh bahwa kekompakan kelompok sebagian besar tergolong pada kategori rendah 93,59\%. Kekompakan kelompok cenderung belum tercapai, karena setiap anggota kelompok sibuk mengerjakan lahan masing-masing. Juga tidak semua anggota terlibat langsung dalam semua kegiatan kelompok sehingga rasa solidaritas atau kebersamaan antara anggota kurang.

Suasana kelompok adalah sikap mental dan perasaan-perasaan yang ada dalam kelompok. Pengukuran dilakukan berdasarkan penilaian responden terhadap tingkatan ketegangan, ramah dan persahabatan, permitif (bebas) dan demokrasi. Berdasar hasil penelitian suasana kelompok berada pada kategori rendah $83,33 \%$. Hal ini berarti suasana yang tercipta di dalam kelompok belum cukup dirasakan oleh anggota kelompok. Ketegangan masih terjadi antar anggota kelompok seperti pada saat ada bantuan bibit, bibit yang diterima disesuaikan dengan luasan lahan yang dimiliki, tetapi anggota kelompok yang lahannya sempit tetap menginginkan bantuan yang sama dengan lahan yang luas.

Tekanan kelompok adalah ketegangan yang terasa dalam kelompok. Pengukuran dilakukan berdasarkan penilaian responden terhadap tingkatan tekanan berasal dari dalam (internal pressure) ataupun luar (external pressure) kelompok. Dari hasil penelitian diperoleh bahwa tekanan kelompok tergolong pada kategori rendah 60,26\%. Dari internal pressure responden menyatakan bahwa terjadi perbedaan pendapat sesama anggota kelompok pada rapat formal maupun pertemuan non formal tetapi tidak sampai terjadi konflik, kalaupun ada dapat dikelola dan memacu upaya pencapaian tujuan kelompok. Sedangkan dari external pressure responden menyatakan bahwa persaingan dengan kelompok tani hutan lain terjadi, tetapi dalam hal yang positif sehingga dapat memacu upaya pencapaian tujuan kelompok. Untuk pemberian hukuman kepada anggota yang bermasalah jarang terjadi sehingga belum pernah dilakukan dan kalaupun terjadi hanya berupa teguran. Hal ini sejalan dengan penelitian Mawikere et al., (2015) bahwa faktor tekanan kelompok hanya berada pada tingkat sedang dipengaruhi oleh sub faktor menerima hukuman. Belum diberlakukannya hukuman bagi anggota yang tidak aktif dalam pertemuan dan kegiatan berdampak pada aktivitas kelompok.

$$
\text { Keefektifan kelompok merupakan }
$$

keberhasilan kelompok dalam mencapai tujuannya. Pengukuran dilakukan berdasarkan penilaian responden terhadap tingkatan dari hasil/ produktivitasnya, dari manfaat kelompok dan dari tingkat kepuasan anggota-anggotanya. Keefektifan kelompok dari hasil penelitian sebagian besar $60,26 \%$ pada kategori tinggi. Hal ini sejalan dengan penelitian Andarwati (2012) bahwa tingginya nilai keefektifan kelompok ini ditunjukkan oleh tercapainya tujuan kelompok, rasa kebanggaan anggota terhadap kelompoknya, serta rasa puasnya anggota terhadap tujuan yang telah dicapai. Hasil wawancara terhadap responden mengenai keefektifan kelompok diketahui bahwa keberhasilan kelompok yang dicapai sesuai dengan tujuan kelompok bersama terlihat dari sebagian responden mengukur pencapaian tujuan melalui kontinuitas usaha, namun sebagian lainnya mengukur pencapaian tujuan dengan peningkatan kesejahteraan memang belum secara signifikan terlihat dan ini dihubungkan dengan hasil tanaman kayu keras yang belum tampak. Sebagian anggota menyadari hal ini dan juga menyadari bahwa salah satu tujuan mereka menanam kayu keras bukan semata-mata diambil manfaatnya secara ekonomi tapi juga sebagai bagian dari upaya konservasi lahan. Tingkat kepuasan dalam pencapaian tujuan kelompok yang dirasakan dalam kelompok dirasakan cukup puas. Sedangkan dari sisi manfaat sudah bisa dirasakan setelah bergabung dengan kelompok sesuai dengan kebutuhan sekarang.

\section{Faktor yang Mempengaruhi Dinamika Kelompok Tani Hutan Agroforestry}

Dinamika kelompok diduga dipengaruhi oleh faktor seperti karakteristik internal anggota, dukungan penyuluhan, dukungan eksternal dan kepemimpinan ketua KTH. Pengujian peubah 


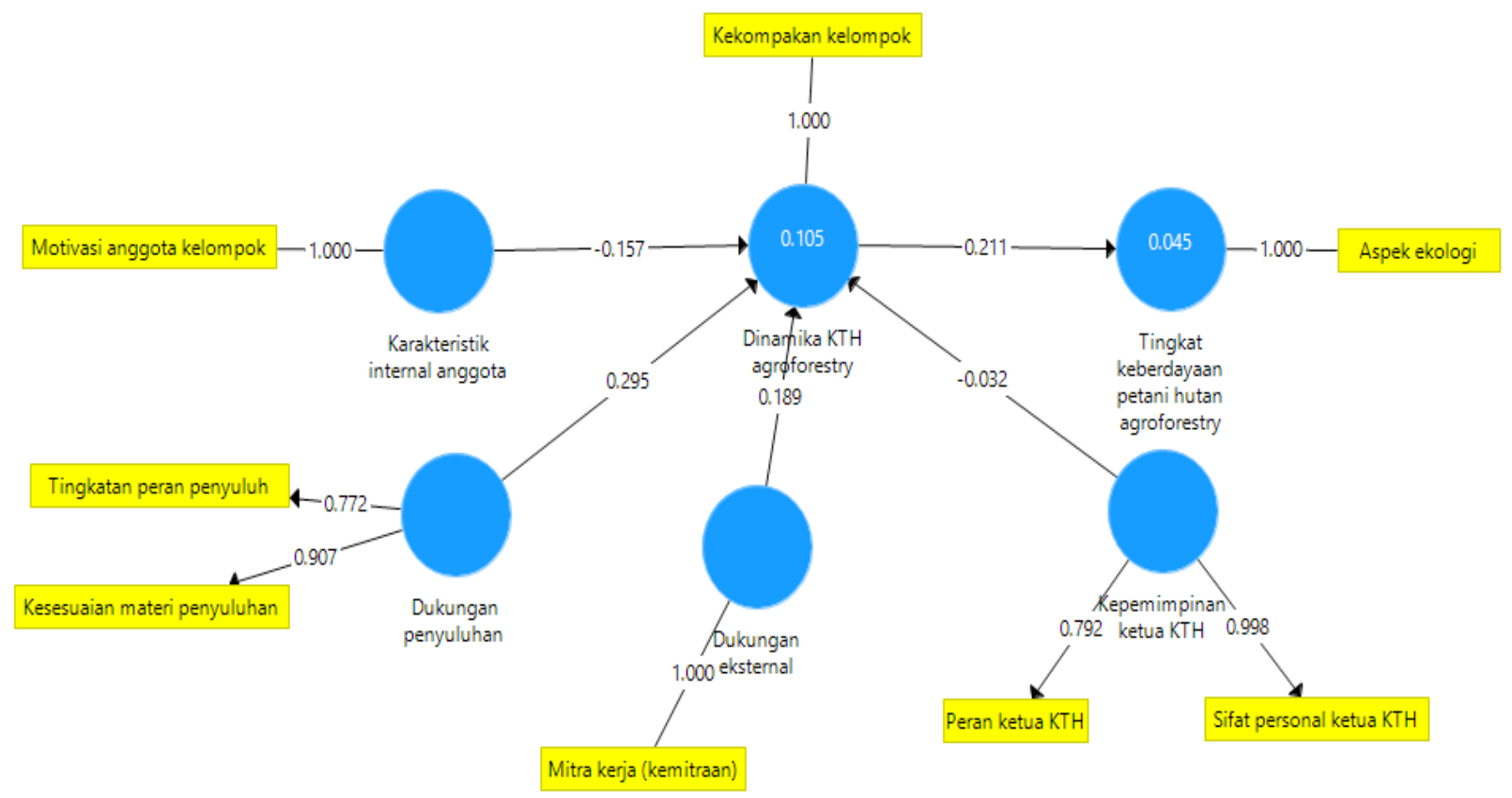

Gambar 1. Model Pengukuran (outer model)

yang memiliki pengaruh dalam penelitian ini menggunakan PLS dengan software Smart PLS version 3.0. Dari keempat faktor di atas dan dari dinamika kelompok itu masing-masing dihubungkan sehingga diperoleh indikator yang mencerminkan faktor. Model menunjukkan pengaruh antara faktor karakteristik internal anggota $\mathrm{KTH}$, dukungan penyuluhan, dukungan eksternal dan kepemimpinan ketua KTH terhadap dinamika kelompok dimana yang paling besar mempengaruhi yaitu dukungan penyuluhan, dukungan eksternal, kepemimpinan ketua KTH dan karakteristik internal anggota KTH. Model pengukuran (outer model) disajikan pada Gambar 1.

Karakteristik internal anggota meliputi umur, pendidikan formal, lamanya menjadi anggota kelompok, pelatihan yang diikuti dan motivasi anggota kelompok. Pada karakteristik internal anggota KTH terdapat satu indikator yang memiliki pengaruh nyata dan langsung yaitu motivasi anggota kelompok. Ada beberapa alasan untuk bergabung dalam kelompok yaitu untuk mendapatkan ilmu pengetahuan, keterampilan, informasi, teman baru dan agar dapat membangun kerjasama kelompok. Motivasi anggota kelompok berpengaruh negatif terhadap dinamika kelompok tani hutan agroforestry. Hal ini berarti bahwa peningkatan motivasi tidak menyebabkan meningkatnya dinamika kelompok.
Rendahnya dinamika kelompok disebabkan motivasi anggota kelompok yang tinggi terkadang terhalang dengan faktor lain seperti anggota harus bekerja, sehingga mereka akan mengikuti kegiatan di kelompok apabila memiliki waktu luang. Indikator motivasi anggota kelompok memiliki nilai factor loading di atas 0,7 yaitu 1.000 sehingga indikator tersebut mampu merefleksikan karakteristik internal. Variabel karakteristik internal anggota terdapat empat indikator yang harus dikeluarkan dari model yakni umur, pendidikan formal, lamanya menjadi anggota kelompok dan pelatihan yang diikuti karena memiliki nilai factor loading di bawah 0,7 yaitu 0,599; 0,470; 0,220 dan 0,103.

Dukungan penyuluhan meliputi intensitas penyuluhan, tingkatan peran penyuluh, ketepatan metode penyuluhan dan kesesuaian materi penyuluhan. Pada dukungan penyuluhan terdapat dua indikator yang memiliki pengaruh nyata dan langsung terhadap dinamika kelompok yaitu tingkatan peran penyuluh dan kesesuaian materi penyuluhan. Sedangkan dua indikator lain yang harus dikeluarkan dari model yakni intensitas penyuluhan dan ketepatan metode penyuluhan. Indikator intensitas penyuluhan dan ketepatan metode penyuluhan memiliki nilai factor loading di bawah 0,7 yaitu 0,498 dan 0,059 sehingga harus dihilangkan dari model. Indikator tingkatan 
peran penyuluh dan kesesuaian materi penyuluhan memiliki nilai factor loading di atas 0,7 yaitu 0,772 dan 0,907 sehingga indikator tersebut mampu merefleksikan dukungan penyuluhan. Tingkatan peran penyuluh dan kesesuaian materi penyuluhan berpengaruh positif terhadap dinamika kelompok tani hutan agroforestry. Hal ini berarti semakin tinggi tingkatan peran penyuluh dan kesesuaian materi penyuluhan maka semakin tinggi pula dinamika kelompok tani hutan agroforestry. Penyuluh mempunyai peran dalam peningkatan dinamika kelompok dan sebagai salah satu sumber belajar bagi anggota kelompok. Begitu pula dengan materi yang sesuai kebutuhan dan permasalahan petani akan mampu meningkatkan dinamika kelompok.

Dukungan eksternal meliputi interaksi sosial kelompok dan mitra kerja (kemitraan). Pada dukungan eksternal terdapat satu indikator yang memiliki pengaruh nyata dan langsung terhadap dinamika kelompok yaitu mitra kerja (kemitraan). Sedangkan satu indikator lainnya yang harus dikeluarkan dari model yakni interaksi sosial kelompok. Pada awalnya indikator interaksi sosial kelompok memiliki nilai factor loading di atas 0,7 yaitu 0,788 , tetapi pada model awal tahap 2 memiliki nilai factor loading di bawah 0,7 sehingga harus dihilangkan dari model. Sedangkan indikator mitra kerja (kemitraan) memiliki nilaifactor loading di atas 0,7 yaitu 1,000 sehingga indikator tersebut mampu merefleksikan dukungan eksternal. Mitra kerja (kemitraan) berpengaruh positif terhadap dinamika kelompok tani hutan agroforestry. Semakin tinggi mitra kerja (kemitraan) maka semakin tinggi pula dinamika kelompok tani hutan agroforestry. Hal ini mendorong kelompok untuk lebih tergerak dengan adanya kemitraan, sehingga kelompok menjadi dinamis.

Kepemimpinan ketua KTH meliputi peran ketua KTH dan sifat personal ketua KTH. Pada kepemimpinan ketua KTH semua indikator memiliki pengaruh nyata dan langsung terhadap dinamika kelompok yaitu peran ketua KTH dan sifat personal ketua KTH karena memiliki nilai factor loading di atas 0,7 yaitu 0,792 dan 0,998 sehingga indikator tersebut mampu merefleksikan kepemimpinan ketua KTH. Peran ketua KTH dan sifat personal ketua KTH berpengaruh negatif terhadap dinamika kelompok tani hutan agroforestry. Peningkatan peran ketua KTH dan sifat personal ketua KTH tidak menyebabkan meningkatnya dinamika kelompok. Rendahnya dinamika kelompok disebabkan peran ketua KTH dan sifat personal ketua KTH yang belum optimal mendorong anggota kelompok ke arah kelompok yang dinamis.

Dinamika kelompok dalam penelitian ini direfleksikan oleh kekompakan kelompok dengan nilai factor loading di atas 0,7 yaitu 1,000 sehingga indikator tersebut mampu merefleksikan

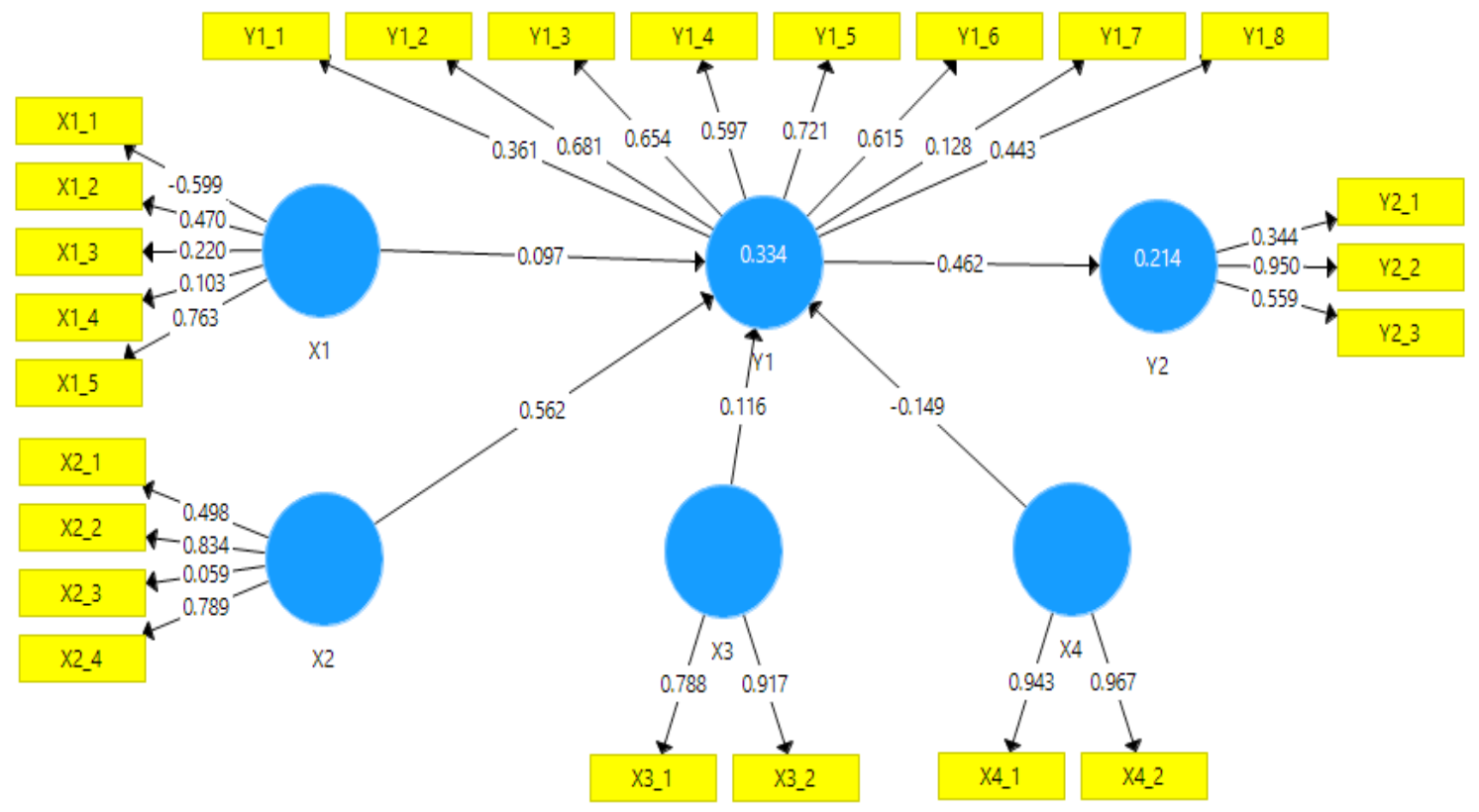

Gambar 2. Model Awal Tahap 1 
dinamika KTH agroforestry. Berdasar analisis outer awal indikator yang lain dikeluarkan yaitu tujuan kelompok 0,361; struktur kelompok 0,681; fungsi tugas 0,654 ; pembinaan dan pengembangan kelompok 0,597; suasana kelompok 0,615; tekanan kelompok 0,128 dan keefektifan kelompok 0,443 karena memiliki nilai factor loading di bawah 0,7 (Gambar 2). Apabila kekompakan kelompok tercapai dan semua anggota terlibat langsung dalam semua kegiatan kelompok juga dengan sifat hubungan kelompok yang harmonis maka semakin tinggi pula dinamika kelompok tani hutan agroforestry.

Dari ulasan di atas tentang faktor yang berpengaruh terhadap dinamika kelompok yaitu faktor karakteristik internal anggota (motivasi anggota kelompok) dan kepemimpinan ketua KTH berpengaruh negatif terhadap dinamika kelompok tani hutan agroforestry. Sedangkan dukungan penyuluhan (tingkatan peran penyuluh dan kesesuaian materi penyuluhan) dan dukungan eksternal (mitra kerja/kemitraan) berpengaruh positif terhadap dinamika kelompok tani hutan agroforestry. Hal ini mengindikasikan bahwa kepemimpinan ketua KTH kurang mendukung pada kekuatan kelompok begitu pula dengan motivasi anggota kelompok. Anggota linier dengan kepemimpinan, sehingga kondisi di dalam kelompok tidak mampu meningkatkan kedinamisan kelompok. Kelompok lebih tergerak dari faktor luar kelompok yaitu dukungan penyuluhan (tingkatan peran penyuluh dan kesesuaian materi penyuluhan) dan dukungan eksternal (kemitraan).

\section{Kesimpulan}

Dinamika kelompok tani hutan agroforestry tergolong dalam kategori rendah yaitu kelompok kurang mampu dalam menggerakkan anggota untuk mencapai tujuan kelompok. Adapun unsur yang rendah pada tujuan, struktur, pembinaan dan pengembangan, kekompakan, suasana dan tekanan kelompok, sedangkan yang kuat adalah unsur fungsi tugas dan keefektifan kelompok. Faktor penyebab rendahnya dinamika kelompok tersebut dipengaruhi oleh rendahnya tingkatan peran penyuluh, ketidaksesuaian materi penyuluhan dan kurangnya kemitraan. Selain itu dipengaruhi oleh tingginya motivasi dan kekuatan kepemimpinan ketua KTH.

\section{Daftar Pustaka}

Andarwati S, Guntoro B, Haryadi FT, Sulastri E. 2012. Dinamika Kelompok Peternak Sapi Potong Binaan Universitas Gadjah Mada di Provinsi Daerah Istimewa Yogyakarta. Jurnal Sains Peternakan. 10(1): 39-46.

Bangsawan I, Hardjanto, Hero Y. 2016. Dinamika Kelompok Tani dan Pembangunan Hutan Rakyat di Kabupaten Serang Provinsi Banten. Jurnal Penelitian Sosial dan Ekonomi Kehutanan. 13(1). 1-12.

Damanik IPN. 2013. Faktor-faktor yang Mempengaruhi Dinamika Kelompok dan Hubungannya dengan Kelas Kemampuan Kelompok Tani di Desa Pulokencana Kabupaten Serang. Jurnal Penyuluhan. 9(1): 31-40.

Havighurst RJ. 1974. Developmental Tasks and Education. Third Edition. New York: David McKay Company Inc.

Karjadi M. 1983. Kepemimpinan (Leadership). Bandung (ID): Karya Nusantara.

[Kemenhut] Kementerian Kehutanan. 2014. Peraturan Menteri Kehutanan Nomor.P. 57/ Menhut-II/2014 tentang Pedoman Pembinaan Kelompok Tani Hutan. Jakarta (ID): Kemenhut. Khodijah N. 2014. Psikologi Pendidikan. Jakarta (ID): Rajawali Pers.

Kusnani DK, Muljono P, Saleh A. 2015. Dinamika Kelompok Penerima CSR PLN Tarahan Lampung Selatan. Jurnal Penyuluhan.11(2): 129-142.

Mawikere MMW, Pangemanan L, Bujung CALD. 2015. Dinamika Kelompok Tani di Kabupaten Bolaang Mongondow. Jurnal Buletin Sariputra. 5(2): 32-36.

Mutmainah R dan Sumardjo. 2014. Peran Kepemimpinan Kelompok Tani dan Efektivitas Pemberdayaan Petani. Sodality: Jurnal Sosiologi Pedesaan.2(3): 182-199.

Putra IGSA, Asngari PS, Tjitropranoto P. 2006. Dinamika Petani dalam Beragribisnis Salak (Kasus di Kabupaten Karangasem Provinsi Bali). Jurnal Penyuluhan. 2(1): 44-52.

Ramadoan S, Muljono P, Pulungan I. 2013. Peran PKSM dalam Meningkatkan Fungsi Kelompok Tani dan Partisipasi Masyarakat di Kabupaten Bima, NTB. Jurnal Penelitian Sosial dan Ekonomi Kehutanan. 10(3). 199-210. 
Riana, Purnaningsih N, Satria A. 2015. Peranan Penyuluh Swadaya dalam Mendukung Intensifikasi Kakao di Kabupaten Sigi Provinsi Sulawesi Tengah. Jurnal Penyuluhan. 11(2): 201-211.

Riduwan. 2012. Pengantar Statistika Sosial. Bandung (ID): Alfabeta.

Ruhimat IS. 2015. Tingkat Motivasi Petani dalam Penerapan Sistem Agroforestry. Jurnal Penelitian Sosial dan Ekonomi Kehutanan. 12(2). 1-11.

. 2017. Peningkatan Kapasitas Kelembagaan Kelompok Tani dalam Pengembangan Usahatani Agroforestry: Studi Kasus di Desa Cukangkawung, Kecamatan Sodonghilir, Kabupaten Tasikmalaya, Provinsi Jawa Barat. Jurnal Penelitian Sosial dan Ekonomi Kehutanan. 14(1). 1-17.

Santosa S. 2006. Dinamika Kelompok Edisi Revisi. Jakarta (ID): Bumi Aksara.

Sari N, Fatchiya A, Tjitropranoto P. 2016. Tingkat Penerapan Pengendalian Hama Terpadu (PHT) Sayuran di Kenagarian Koto Tinggi, Kabupaten Agam, Sumatera Barat. Jurnal Penyuluhan. 12(1): 15-30.

Sarwono J, Narimawati U. 2015. Membuat Skripsi, Tesis dan Disertasi dengan Partial Least Square SEM (PLS-SEM). Yogyakarta (ID): Penerbit Andi.

Sudarko. 2010. Hubungan Dinamika dan Peran Kelompok dengan Kemampuan Anggota dalam Penerapan Inovasi Teknologi Usaha Tani Kopi Rakyat (Kasus di Desa Sidomulyo Kecamatan Silo Kabupaten Jember Jawa Timur) [tesis]. Bogor (ID): Institut Pertanian Bogor.

Suryani A, Fatchiya A, Susanto D. 2017. Keberlanjutan Penerapan Teknologi Pengelolaan Pekarangan oleh Wanita Tani di Kabupaten Kuningan. Jurnal Penyuluhan. 13(1): 50-63. 